\title{
2: A System of Wholesale Denial of Rights
}

MR monthlyreview.org/2007/09/01/a-system-of-wholesale-denial-of-rights/

\section{by Michael E. Tigar Topics: Imperialism , Political Economy}

Michael E. Tigar is a lawyer and law professor. He teaches at American University, Duke, and the Faculté de droit et de science politique in Aix-en-Provence. He is the author of Law and the Rise of Capitalism (Monthly Review Press, second edition, 2000). (See part one of the Review of the Month by Jean-Claude Paye.)

As in the past, Americans owe Jean-Claude Paye a debt of gratitude. From his position, as a sociologist in Brussels, he has proven that he can see what is happening in George Bush's and Dick Cheney's America, more clearly perhaps than many who live in the United States.

As Paye notes, there are two important aspects to the regime created by the Detainee Treatment Act of 2005 (DTA) and the Military Commissions Act of 2006 (MCA). The MCA recognizes a distinction between "enemy combatants" who are citizens of the United States and those who are aliens. Alien enemy combatants are, as Paye notes, subjected entirely to the regime of military commissions and denied access to civil courts except under limited circumstances. Citizen enemy combatants have access to civil courts, but find their rights constricted in other ways. The alien-citizen distinction in the MCA is a congressional response to the Supreme Court's decision in Hamdan v. Rumsfeld, in which a five-justice majority held that the president did not have the power to strip citizens and aliens alike of their right of access to civil courts and to the writ of habeas corpus. The Court invited the president to return to Congress to validate his claims of power, and Congress obligingly did so, thus proving that there are few persons in the elected leadership willing to raise a voice against the imperial powers of which Paye writes.

For Americans having some direct or vicarious experience in the political struggles of the past six decades-that is to say since the 1940s - the definition of enemy combatant is chillingly familiar. The initial determination of culpability is made based on either (1) membership in or affiliation with al Qaeda, which is hardly an organization in the sense of having a defined structure, or (2) conduct that amounts-with some exceptions that I note below-to material support of hostilities against the United States. The definition of enemy combatant may also attach even to those who engage only in acts that are merely preparatory, or done with a forbidden intention without provable present danger or effect. The elastic and elusive meaning of "al Qaeda," coupled with the vagueness and overbreadth of prohibited association, vests unfettered discretion in executive officers who are in charge of rounding up and detaining suspects.

This broad-gauge approach is not new, but rather an extension into new territory of a definitional structure adopted by the Clinton administration in 1994, and based upon ideas that have been central to repressive legislation for decades past. To evaluate this assertion, let us consider some basic principles of constitutional law.

The First Amendment protects freedom of speech and association. Under the Supreme Court's decision in Brandenburg v. Ohio, speech that advocates unlawful violence is constitutionally protected unless uttered with the intent to cause such violence imminently and under circumstances showing a clear and present danger that this is what is about to happen. That is, one can believe, teach, and advocate that U.S. policy is wrong, that the alleged enemies of the United States should prevail, that socialism should replace capitalism, and-as Brandenburg was himself advocating - that people wreak vengeance on public officials.

A second and related idea is that one is free to associate with a group that has demonstrably unlawful objectives, absent proof that one intends by one's actions to further those objectives. After all, many political associations engage in both lawful and unlawful activity. In the 1961 case of Noto v. United States, the Supreme Court reversed a conviction for membership in an organization devoted to overthrowing the government; the prosecution had not proved that Noto's membership went beyond supporting the constitutionally protected activities of the organization. 
And note that those latter activities might well include advocacy of violence.

The most sweeping repudiation of the constitutionally based limiting principles introduced by the Clinton administration's 1994 definitional structure is in connection with the term "material support." If someone in the United States sent munitions to a group that was engaged in armed conflict with U.S. forces, that would be the sort of "material support" that one could understand and that would form the basis for valid and limited criminal laws. However, that term has been part of several laws prohibiting actions that allegedly support terrorism since at least 1994. In the Patriot Act and related legislation, the term has acquired an enormously expanded meaning.

If an alien-someone not a citizen-is compelled to serve as a cook or nurse for Taliban forces or some group allegedly tied to al Qaeda, that person has provided material support and is subject to exclusion from asylum in the United States and possible designation as an enemy combatant. If a group of people in the United States contribute to a Muslim charity based in a foreign country, some of whose activities are alleged to support actions contrary to U.S. interests, they become targets of prosecution for material support and for designation as enemy combatants.

The definition of material support has thus gone beyond limits dictated by the nature of the support provided, or indeed to a large extent the intention with which it was given. This stretching of the ordinary meaning of words has occurred in circumstances even more dangerous to the right of political speech. Consider the case of Lynne Stewart, a courageous lawyer in New York, who now stands convicted of, among other things, agreeing to provide material support to an organization devoted to violence.

The organization in question is the Egyptian Islamic Group, long an opponent of the repressive Egyptian government. That government has, even according to the annual country reports by the U.S. Department of State, an abysmal human rights record. Lynne Stewart was trial counsel for Sheikh Abdel Rahman in New York in 199596. Sheikh Abdel was charged with complicity in the 1993 World Trade Center bombing and convicted on doubtful evidence.

After his conviction, he was put into solitary confinement in a prison hospital. He is blind, aged, and a diabetic. He does not speak English. His sole contact with the world outside prison was by means of visits from his legal team and occasional telephone conversations with his wife and other close family members. These latter conversations were monitored overtly, and many of his lawyer visits recorded covertly.

Lynne Stewart gave two interviews to the Egyptian press, reporting Sheikh Abdel Rahman's views on whether the Islamic Group should continue its policy of not engaging in armed struggle against the Egyptian regime. These statements did not advocate violence. They simply raised the issue of whether nonviolence was a preferable path, and left the issue to those in Egypt; those in Egypt decided to maintain the policy of nonviolence. No person was killed or even harmed as a result of these statements.

The government claimed, and the trial court agreed, that Stewart provided "material support" in the form of "personnel," by repeating her client's statements. That is, the Bush administration successfully argued that political speech on a matter of public interest, without proof of clear and present danger, was classifiable as unlawful.

These observations suggest the danger that lurks in the expanding definitions of criminal support for alleged terrorism. However, in most of the cases, including Lynne Stewart's, the regular courts are open and available to make arguments about constitutional protection. Asylum-seekers, however, do not have such rights; there are avenues of judicial review available to them, but these are provably inadequate. The expanding criminalization of speech and association traces paths familiar to those involved in the political struggles of past decades.

Citizens classified as enemy combatants under these expansive definitions will at least have access to civil courts. We shall see whether those courts will exercise judgment independent of presidential proclamation. The legislative branch has not set a good example of independence. Recent decisions by federal courts in cases related to the "war on terrorism" have contained some courageous statements on governmental overreaching as well as some 
distinctly supine acceptance of executive power.

\section{The Radical Departure}

But as Paye notes, the most radical departure of the proclamations, the DTA and the MCA, is with respect to aliens who are deemed "enemy combatants." As Paye notes, the administration's evident intention is to deny any such person the right of habeas corpus, that is access to a civilian court where the government must prove by lawful and reliable evidence that it has the right to hold the detainee. Moreover, this unreviewable detention is claimed to be of indefinite duration, and under conditions of solitary confinement, with interrogation practices that in the view of many amount to torture, without access to independent counsel, and with no right in any forum to make a meaningful challenge or denial.

One needs to be clear about this. Those of us engaged in representing detainees do not concede that the civil courts have no power, and that the Bush administration's objective can go unchallenged. We shall see. But one must examine the administration's claim to see that it in fact represents a qualitative rupture with the claimed system of constitutional governance. Abandoning the pretense of the state as neutral arbiter, the administration has unilaterally abrogated the social contract of which constitutional jurists have often spoken.

To be sure, the contract reference is somewhat figurative, but no less powerful for all that. The most celebrated example is the case of Judith Coplon, an American lawyer accused in 1949 of attempting to commit espionage on behalf of the Soviet Union. The FBI had conducted illegal wiretaps to collect evidence against her, and resisted disclosing them to the court. Learned Hand, writing for the court of appeals, held that the wiretaps must be disclosed, so that the court could determine whether the prosecutors had used unlawfully obtained evidence in Coplon's prosecution. Judge Hand expressed the idea that the government cannot have it both ways. Once it decides that someone should be punished, it cannot retreat behind a curtain of "state secrecy" and deny the defense access to information that may lead a jury to acquit, even if that information is the most sensitive "national security" material that can be imagined.

To take an even broader perspective, the Constitution contains a number of specific provisions that govern the ways in which the state can inflict punishment on people. The Sixth Amendment says that "in all criminal prosecutions," the accused shall have the right to counsel, to jury trial, to confront the evidence against him or her, and so on. The Fifth Amendment says that no person shall be deprived of life, liberty, or property without due process, which means at least an impartial tribunal that hears reliable, lawful evidence. That amendment also says that "no person" shall be tried for a serious crime except after indictment by a grand jury. Criminal trials are to be presided over by a judge appointed for life and nominally independent of the executive branch, and this is not only by Article III of the Constitution but the long tradition that it embodies. Under the Fourth Amendment, a judicial warrant is necessary to authorize searches; the amendment was written by people familiar with the concept of treason and revolution, but grants the executive branch no exceptions for such cases.

There are exceptions to these principles, but the only one that is possibly relevant is the provision that Congress can "make rules for the government and regulation of the land and naval forces," which includes the power to establish courts martial for offenses within military jurisdiction. The MCA system for trying alien enemy combatants does not provide even the protections given a defendant in a general court martial; more on this issue later.

The Constitution also confers upon Congress the power to define and punish piracy and other offenses against the law of nations. At the time the Constitution was adopted, there were plenty of aliens shooting at Americans and taking their property and otherwise endangering international peace. These people were called "pirates." Congress possesses carefully defined constitutional powers with respect to piracy. The practice in 1787 was to capture pirates and bring them into port for trial. 1

Thus, the system of federal criminal law and procedure established by the Constitution is, on a careful reading, allinclusive and not admitting of exceptions. We must, however, acknowledge that the history of armed conflict has 
revealed instances where civilians and soldiers were treated in ways that do not meet the standards the Constitution established. The international community has addressed this issue directly, and the United States is party to a series of treaties that protect combatants and civilians when there is armed conflict. Most of these protective principles are codified in the Geneva Conventions, which protect prisoners of war and noncombatants, and the Hague Conventions, which regulate the conduct of warfare. Rules of customary international law supplement and extend these protections.

It was generally understood until the Bush administration's proclamations and the ensuing legislation that this Constitution and treaty-based system did indeed cover all the possibilities for the United States detaining, trying, and punishing people who were engaged in or affected by armed conflict. There is, in these concepts of "enemy combatant," and particularly "alien enemy combatant," as people without rights and without the means to enforce rights, a chilling reminder of an earlier dark chapter in American history. I refer to chattel slavery. The Bush administration has reverted to a juridical technique of finding a hole in the constitutional fabric, through which will fall all members of this denominated class of persons-alien enemy combatants.

Almost everyone recognizes the name Dred Scott, and has heard of the Dred Scott case. Dred Scott was born into slavery, in about 1795. In the 1830s, his owner lived and worked in Illinois and in the Wisconsin Territory. Under Illinois law at that time, a slave brought into the state was regarded as free, and would not regain slave status upon return to a state in which slavery was legal. During this period, there were fierce political battles, and even armed conflict, over the issue of extending slavery as new territory was incorporated into the United States and new states were created.

When Scott's master returned to Missouri, a slave state, he hired Scott out as a slave, which was unlawful under Illinois law but apparently permitted under the law of Missouri. Scott sued, first in state court and then in federal court, to have his freedom recognized. His litigation was supported by abolitionist lawyers and their supporters.

Scott claimed that the federal court had jurisdiction over his case because he was a citizen of Missouri and his "owner," Sanford, was a citizen of New York. This was a claim of diversity of citizenship, a category recognized explicitly in the federal Constitution and in the first Judiciary Act. Scott claimed that Sanford had assaulted him, but the heart of the case was the claim-necessarily involved in the claim of assault, that Scott was a free person entitled to have his rights respected.

The case finally arrived in the Supreme Court in 1854, and the Court heard days of argument in February and again in December 1856. By that time, the slavery controversy was at the center of political attention. James Buchanan was elected president in 1856, to be inaugurated on March 4, 1857. Buchanan attempted to influence the Court's members to decide the case against Scott, hoping that such a decision would establish the constitutional position of slavery and end the national debate on the subject.

The Court issued its judgment by a vote of six to three, on March 6, 1857, two days after Buchanan's inauguration. The lead opinion was by Chief Justice Roger Taney of Maryland. The Court held that Scott was not a citizen of Missouri and indeed lacked the capacity to be a citizen of any state. It then went on to hold that territorial legislatures -and by necessary inference state legislatures_lacked the power to enact legislation that gave slaves their freedom upon entering the territory. Such statutes, Taney said, would deprive slave owners of their property.

A few celebrated quotations from Taney's opinion will remind readers of how telling is the analogy to what the Bush administration is now trying to do:

$[\mathrm{N}] \mathrm{o}$ State, since the adoption of the Constitution, can by naturalizing an alien invest him with the rights and privileges secured to a citizen of a State under the Federal Government, although, so far as the State alone was concerned, he would undoubtedly be entitled to the rights of a citizen, and clothed with all the rights and immunities which the Constitution and laws of the State attached to that character. 
[N]o State can, by any act or law of its own, passed since the adoption of the Constitution, introduce a new member into the political community created by the Constitution of the United States.

Those who wrote the Constitution, Taney said, thought that Africans, slave or free, were "beings of an inferior order, and altogether unfit to associate with the white race, either in social or political relations, and so far inferior that they had no rights which the white man was bound to respect." Indeed, said Taney, accepting Scott's position "would give to persons of the negro race...the right to enter every other State whenever they pleased...the full liberty of speech in public and in private upon all subjects upon which its own citizens might speak; to hold public meetings upon political affairs, and to keep and carry arms wherever they went."

The decision in Dred Scott made the Civil War inevitable. Abolitionists, such as Frederick Douglass, had held hope that slavery might be abolished by constitutional interpretation. He read the Constitution differently than did Taney, as recognizing slavery in two important respects: first, by providing that a slave would be counted only as three-fifths of a person for purposes of taxation and allocation of legislative seats, and as barring Congress from prohibiting the slave trade until 1808. Second, it was clear from article 1, section 2 of the Constitution that slaves were "persons" within the meaning of the Constitution and that they counted for at least something in giving congressional seats to slave states.

Taney and the Court majority—mostly Southerners—could have decided the other way by relying on the "persons" language of the Constitution, and by careful study of the Court's earlier decisions involving slavery. In 1825, Chief Justice John Marshall, in a case entitled the Antelope, had written for the Court that slavery and the slave trade as then practiced did not violate international law, and by extension the Constitution. However, in 1841, the famous slavery case - the Amistad — came to the Supreme Court, and was widely supported by abolitionist forces. The Court's decision, written by Justice Joseph Story, did not say that slavery was unconstitutional. However, it upheld the rights of Africans on board a slave ship to rise up and mutiny in order to defend their claim to freedom. Justice Story referred to "eternal principles of justice and international law."

Implicit even in the Antelope, and expressly in the Amistad, is the idea that Africans who claim freedom are persons entitled to the law's respect. "Respect" means nothing unless there is a mechanism to have it enforced by state power. The Dred Scott decision simply held that there was a category of human beings utterly excluded, by definition, from the constitutional compact-except to the limited extent that some states might allow Africans to be free-and provided that if they had been slaves their owners were compensated.

Dred Scott, in the telling phrase used by my colleague Muneer Ahmad, had "no right to have rights," according to the Court's majority. As a direct consequence of the Civil War that the Dred Scott decision made inevitable, the Thirteenth Amendment to the Constitution abolished slavery. The Fourteenth Amendment made express what one had thought should be implicit in the Constitution:

All persons born or naturalized in the United States, and subject to the jurisdiction thereof, are citizens of the United States and of the state wherein they reside. No state shall make or enforce any law which shall abridge the privileges or immunities of citizens of the United States; nor shall any state deprive any person of life, liberty, or property, without due process of law; nor deny to any person within its jurisdiction the equal protection of the laws.

Of course, after 1872, the Southern states made a virtual dead letter of these Fourteenth Amendment commands by enacting "Black Codes" that excluded the former slaves from all the rights of persons and citizens, and these legal barriers were not struck down until the mid-twentieth century. Their effects persist today.

This idea that the state can exclude a class of persons from all means to enforce claims for justice did not originate in the Dred Scott decision itself, nor necessarily in the legal ideology of slavery. Earlier in the nineteenth century, the Cherokee Nation of Native Americans had organized in order to resist white settlers taking its historically occupied lands. It went into federal court to vindicate its claims against the state of Georgia. As I wrote in the second edition of Law and the Rise of Capitalism: 
The Cherokee Nation of Georgia adopted a written constitution and asserted sovereignty over its land. The Georgia legislature responded by declaring Cherokee laws and customs void and opening Cherokee land to settlement. The federal Congress, at the urging of President Andrew Jackson, passed legislation seeking to compel Native Americans to give up and move Westward. Georgia authorities arrested, tried and hanged a Cherokee for an offense allegedly committed on Cherokee territory.

The Cherokee Nation sought relief in the Courts. 2 They were, after all, a nation. They sought to restrain the enforcement of Georgia laws which "go directly to annihilate the Cherokees as a political society, and to seize, for the use of Georgia, the lands of the nation which have been assured to them by the United States in solemn treaties reportedly made and still in force." The Cherokee's lawyer invoked the Supreme Court's power, saying that the lawsuit was between a foreign nation-the Cherokee-and the State of Georgia. Under the United States Constitution, the Supreme Court could exercise its original jurisdiction over such a lawsuit—without waiting for lower courts to decide it and then hearing the case on appeal.

Chief Justice Marshall looked to the constitutional grant to Congress of the power to regulate commerce with "foreign nations, and among the several states, and with the Indian tribes." He found the Cherokee to be "a domestic, dependent nation" that was "in a state of pupilage," like "that of a ward to his guardian." It was not, he said for the Court a true "foreign nation." Thus, the Cherokee Nation had no legal existence. It could not even come to a federal court to vindicate its treaty rights.

The Court decided Cherokee Nation v. Georgia in 1830, over the dissents of Justices Story and Thompson. Two years later, in Worcester v. Georgia,3 Chief Justice Marshall retreated a bit, and held that Georgia did not have the right to regulate activities on the Cherokee lands. He did not reach this result by recognizing the position of the Cherokee nation, but by denigrating the right of a state such as Georgia to interfere in matters that are essentially federal. That is, the national government had the constitutional power to deal with Native Americans and the states had only a limited role to play.

Cherokee Nation is an early formulation of imperialist ideology, justifying the exclusion of "subject peoples" from any access to forums in which they might assert their rights by invoking a plenary and unreviewable power in the hands of executive power. The common thread that runs through Cherokee Nation, Dred Scott, and the enemy combatant characterization of which Paye writes is this complete exclusion of claims for justice from any possibility of discussion.

By contrast, a political group or an individual may invoke rights to freedom of expression and association. Having gained access to a constitutionally created tribunal, the court will engage in a debate about how those ideas should be expressed in rules of conduct. The court will then evaluate the facts and apply those rules.

The experience of decades teaches us that these constitutionally created courts often defer unreasonably to the executive branch, as to how rules should be formulated and facts determined. The constitutional promise of impartiality is another lie the regime tells the people. Even when the process can be seen as fair, there is no guarantee against unjust results. The point, however, is that the regime is the general run of cases telling the people that there is access to something that calls itself justice, and that the tribunals established under that promise engage in certain defined procedures that contribute to a sense that the results are fairly arrived at.

The newly invented enemy combatant category, particularly when applied to non-citizens, short-circuits the connection between state power and the person against whom that power is to be exercised. The Bush administration invokes characterization - a label - to take any question of rights out of the debate. This is a familiar technique to students of bourgeois legal history. In 1842, Marx wrote an essay on "the law relating to thefts of wood," and described how the Prussian state had made a peasant mode of living illegal by the simple device of declaring fallen branches to be the property of the person who owned the tree. Peasants who had historically gathered the fallen branches to build cooking and heating fires were thus further marginalized and forced into the ranks of wage laborers. The English Black Acts of 1721 and after, so brilliantly chronicled by E. P. Thompson, worked the same 
kind of harm on the English peasantry, and with the same objective.

One should also call to mind the Supreme Court's decision in Romer v. Evans. Many Colorado cities had adopted legislation protecting gay rights in various ways. In a statewide referendum in 1992, Colorado voters approved a state constitutional amendment that prohibited all legislative, judicial, or executive action at any level of state government that would recognize the rights of gay people to be free from discrimination. The U.S. Supreme Court held that this state constitutional amendment violated the equal protection clause of the Fourteenth Amendment of the U.S. Constitution. Justice Kennedy, speaking for the majority of six justices, said that the law singled out gay people as having no right whatsoever to seek redress against discrimination. In private conversation, Justice Kennedy has said that to him the Colorado provision seemed like the Dred Scott decision in its intent and effect.

The Court's decision in Romer, and Justice Kennedy's comment, calls to mind another idea about the enemy combatant classification. The proclamations and statutes create a class of persons who are asserted to possess certain dangerous characteristics. These persons are to be hauled before commissions to determine which specific characteristics they have allegedly exhibited by their conduct. This is a classic bill of attainder, forbidden by the Constitution. For example, in United States v. Brown, the Supreme Court struck down a statute that made it a crime for a member of the Communist Party to hold a labor union office, because the statute created a class of suspect persons and singled them out for punishment without requiring a judicial trial to decide if they had done any particular wrongful acts.

It remains to examine the ostensible justification for creating a system that permits wholesale denial of rights. Already, the newspapers are carrying reports that this or that detainee has confessed to participating in armed action against American targets, and military officers are being quoted in the press as promising more such revelations. A quick response to these reports is a rhetorical "does anyone believe anything this administration says?," coupled with another shake of the head at how credulous most of the media have become.

A more serious answer lies in the texts of the presidential proclamations and congressional enactments themselves. While the MCA expressly disavows torture, it insulates Americans who practice it from liability. The government argues that it permits use in evidence of statements obtained in violation of this limited prohibition, prior to the statute's enactment. Moreover, President Bush has accompanied his signature on the legislation with a signing statement that casts doubt on whether the statute's command will be obeyed. In any event, the administration has taken so limited a view of what torture entails as to encourage forms of interrogation long condemned by the international community. In short, these alleged "confessions" are the product of long, solitary, and inhuman detention accompanied by interrogations that have historically been denounced as leading to untrue acceptance of liability. As I write these words, eighteen British sailors are in Iranian custody for violating Iran's territorial waters. At least one of the sailors has appeared on television apologizing for the intrusion. Much of the press carries this statement as a "confession," with the word in quotation marks signifying distrust of Iran's interrogation methods, while the same publications omit the quotation marks when discussing Guantánamo.

When there is any inquiry, from citizens, media representatives, or even the legislative branch about exactly what methods of interrogation are being used at Guantánamo and other, even more isolated, prisons, the administration is quick to claim that this is a state secret. Indeed, in the Guantánamo proceedings, the government has sought to prevent lawyers from knowing the interrogation techniques, assertedly because if terrorists knew how they would be interrogated, they could prepare themselves to withstand the methods to be used.

One recent disclosure from Guantánamo is that a Tanzanian, Ahmed Ghailani, and a Pakistani, Walid abin Attash, confessed to helping plan the 1998 bombing of the U.S. embassies in Tanzania and Kenya. They are among detainees recently transferred to Guantánamo from secret CIA prisons. In those prisons, they were without doubt subjected to torture. What will happen to these two men? They are subject to a death penalty at the hands of a military commission, and have already been punished by their confinement and treatment, without any judicial trial or opportunity to obtain review of their detention or conditions. Readers may recall that in 2001, four men were tried in New York federal court for participating in the embassy bombings. The government sought the death penalty. 
One defendant, Khalfan Khamis Mohamed, was arrested in South Africa, having gone there from Tanzania. The FBI and some lower-level South African officials fabricated a story that he had consented to be sent to the United States to face a capital trial, and on this basis he was flown to New York.

The South African Constitutional Court took the case and held that the rendition was unlawful under South African and international law. The court's judgment exposed the fraudulent means used to bring Mohamed to the United States. Under American law, however, the illegal rendition did not prevent him from being tried. At his trial, Mohamed was convicted, but Judge Sand instructed the jury that it could consider in mitigation of a potential death sentence that if the United States had obeyed the law, Mohamed would not have faced the prospect of a death sentence. This was an accurate statement because, among other reasons, South Africa would never permit a lawful extradition without attaching a condition that the defendant could not face capital punishment.

At the federal trial defendants had the right to confront and cross-examine witnesses, and were guaranteed that the judge would consider whether evidence was lawfully obtained. In that trial, the jury refused to approve a death sentence for any defendant.

In the cases of Ghailani and Attash, the United States has found a way to avoid all the inconveniences of due process, because now they are no longer "persons" entitled to such a thing. The "alien enemy combatant" characterization has short-circuited all entitlement to a judicial trial for a crime clearly defined and clearly within the congressionally defined jurisdiction of U.S. courts and juries. One should recall that in the CIA prisons, such as the one where Ghailani was held, the Bush administration claims that no treaty limits the interrogation techniques that may be used; the Bush administration and the CIA take the position that congressional restrictions on interrogation in the MCA do not apply to CIA interrogators. In fact, Ghailani is named in the indictment under which the four defendants tried in 2001 were charged. The Bush administration's proclamation took a criminal defendant out of the process in order to deprive him of rights.

I do not, of course, harbor the illusion that people of color, or those of any color accused of complicity with terrorists, in "ordinary" criminal cases are routinely treated in a constitutionally respectful way. I have written on that subject in Monthly Review.4 As Roland Barthes has written, the system that calls itself "justice" is always ready to judge you as you must be, and not as you are-as a social construct and not as a human being. But when the system behaves in these ways, one has at least the opportunity to compare its performance with the state's own proclaimed standards, and to have the benefits of publicity and courtroom confrontation.

We, the lawyers, will continue our work, seeking to bring these issues into the open in the forums that remain available to us, and advancing all the arguments and interpretations that we can think of. Our commitment to this important work should not lead anyone, and perhaps especially us, to ignore what is happening as the state unilaterally casts aside any pretense of impartiality or of an obligation to act in fair and accountable ways.

\section{Notes}

1. $\hookleftarrow$ Indeed, if the pirate was an alien, he would get the additional protection of a jury, half of whose members were aliens—the jury "de mediatate linguae." See Respublica v. Mesca, 1 Dall. 73, 1 L.Ed. 42; People v. McLean, 2 Johns.(N.Y.) 381. This practice has been abrogated. See United States v. Wood, 299 U.S. 123, 145 (1936).

2. $\hookleftarrow$ Cherokee Nation v. Georgia, 30 U.S. 1 (1830).

3. $\hookleftarrow 31$ U.S. 515 (1832).

4. $\hookleftarrow$ Michael E. Tigar, "Lawyers, Jails, and the Laws Fake Bargains," Monthly Review 53, no. 3 (July-August, 2001), 29-41, http://monthlyreview.org/0701tigar.htm. 